\title{
Meningkatkan Hasil Belajar PKn tentang Lembaga Pemerintahan Desa
}

\author{
Riswanto \\ UPK Kecamatan Lumbir \\ Butulan, Lumbir, Kec. Lumbir, Kabupaten Banyumas, Jawa Tengah \\ Email: bdmartono7@gmail.com
}

\begin{abstract}
Abstrak
Salah satu tujuan pendidikan nasional adalah mencerdaskan kehidupan bangsa, namun upaya untuk mewujudkan tujuan pendidikan tidaklah mudah. Pada kenyataannya banyak hambatan yang di hadapi baik oleh peserta didik maupun oleh guru. Tingkat penguasaan materi pembelajaran di SD Negeri Lumbir UPK Lumbir belum sesuai dengan kreteria keberhasilan. Oleh karena itu guru perlu mengadakan perbaikan pembelajaran melalui Penelitian Tindakan Kelas (PTK). Penelitian Tindakan Kelas diawali dengan refleksi diri, mendiskusikan dengan teman sejawat (kolabor), mengetahui permasalahan yang dihadapi dan menemukan alternatif pemecahan yang terdiri dari kegiatan perencanaan, pelaksanaan, pengamatan dan refleksi pada setiap siklusnya. Pada penelitian ini guru menggunakan metode karyawisata yang akan dibagi menjadi tiga siklus yang masing-masing siklus terdiri dari dua pertemuan. Tujuan penelitian ini adalah untuk meningkatkan hasil belajar siswa.

Setelah dilakukan penelitian melalui 3 siklus dengan Kretiria Ketuntasan Minimal (KKM) 7,5 diperoleh hasil yang meningkat setiap siklusnya dari studi awal hanya 3 anak yang tuntas belajar atau 18\%, siklus I sebanyak 6 anak yang tuntas belajar atau 37\%, siklus II sebanyak 10 anak tuntas belajar atau 62\% dan siklus III sebanyak 14 anak tuntas belajar atau $87 \%$ dari jumlah siswa kelas IV sebanyak 17 siswa. Jadi, penggunaan metode karyawisata berhasil meningkatkan keaktifan dan hasil belajar siswa. Setelah melaksanakan penelitian ini hendaknya guru dapat menggunakan metode yang tepat dan dapat meningkatkan hasil belajar siswa sehingga pembelajaran berhasil dan efektif.
\end{abstract}

Kata Kunci : Metode karyawisata, hasil belajar PKn

\begin{abstract}
One of the goals of national education is to educate the life of the nation, but efforts to realize the goals of education are not easy. In fact, there are many obstacles faced by both students and teachers. The level of mastery of learning material in SD Lumbir State Lumbir UPK is not in accordance with the criteria of success. Therefore teachers need to make improvements to learning through Classroom Action Research (CAR). Classroom Action Research begins with self-reflection, discussing with colleagues (collaborating), knowing the problems faced and finding alternative solutions that consist of planning, implementing, observing and reflecting in each cycle. In this study the teacher uses the field trip method which will be divided into three cycles, each cycle consisting of two meetings. The purpose of this study is to improve student learning outcomes.

After conducting research through 3 cycles with Minimum Completion Criteria (KKM) 7.5, the results obtained increased each cycle from the initial study to only 3 children who completed learning or $18 \%$, the first cycle of 6 children who completed learning or $37 \%$, cycle II as many as 10 children completed study or $62 \%$ and cycle III 14 students completed study or $87 \%$ of the total grade IV students were 17 students. So, the use of field trip methods has succeeded in increasing student activity and learning
\end{abstract}


outcomes. After carrying out this research teachers should be able to use appropriate methods and can improve student learning outcomes so that learning is successful and effective.

Keywords: Field trip method, Civics learning outcomes

\section{PENDAHULUAN}

Peneliti adalah seorang wali kelas V di SD Negeri 2 Lumbir UPK Lumbir Kabupaten Banyumas. Peneliti mengalami masalah dengan pembelajaran yang telah dilaksanakan selama beberapa kali. Permasalahan tersebut adalah rendahnya hasil belajar siswa pada mata pelajaran IPA pada materi organ pencernaan manusia. Siswa sangat sulit memahami bagian-bagian organ pencernaan manusia, serta tidak bisa menjelaskan fungsi masing-masing organ tersebut bahkan sering diam dan bingung saat ditanya. Melalui hasil tes awal yang dilakukan melalui pemberian soal evaluasi hasilnya pun sangat mengecawakan. Kriteria Ketuntasan Minimal (KKM) mata pelajaran IPA kelas V di SD Negeri 2 Lumbir adalah 70. Setelah dilaksanakan pembelajaran pada tahap pra siklus, peneliti cukup kecewa karena dari jumlah 20 siswa hanya ada 4 siswa yang tuntas atau jika diprosentasi sebesar 20\%, sedangkan siswa yang belum tuntas lebih banyak yaitu 16 siswa atau jika diprosentase sebesar $80 \%$. Dengan tingginya angka prosentase siswa yang belum tuntas pada mata pelajaran IPA peneliti merencanakan untuk memperbaiki pembelajaran. Peneliti selama ini hanya menggunakan metode ceramah, tanya jawab dan penugasan saja. Untuk memperbaiki pembelajaran peneliti akan merubah model pembelajaran dengan menggunakan model Think Pair Share. Model pembelajaran Think Pair Share adalah model pembelajaran dengan cara meminta siswa untuk berdiskusi dengan teman sebangku (think-pairs) dan kemudian presentasi kelompok (share), lalu diadakan kuis dan siswa yang mendapatkan skor tertinggi akan mendapatkan penghargaan. Melalui model pembelajaran tersebut diharapkan dapat membantu siswa untuk memahami materi dan meningkatkan hasil belajar siswa. Perbaikan pembelajaran akan dilaksanakan secara bersiklus, apabila pada siklus I belum berhasil maka peneliti akan melanjutkan ke siklus II. Namun peneliti mempunyai target bahwa perbaikan pembelajaran maksimal dilaksanakan selama 2 siklus, sehingga peneliti akan berusaha semaksimal mungki agar perbaikan pembelajaran tersebut dapat berhasil. Adapun hasil belajar siswa pada pembelajaran IPA dapat kita lihat pada tabel berikut. 
Tabel 1. Hasil Belajar IPA pada Tahap Pra siklus

\begin{tabular}{|c|l|cc|}
\hline No. Absen & \multicolumn{1}{|c|}{ Nama Siswa } & Nilai & Ket \\
\hline 1 & Didit Kurniawan & 40 & Belum Tuntas \\
2 & Erni Ardita & 50 & Belum Tuntas \\
3 & Kurniawan & 50 & Belum Tuntas \\
4 & Purwanto & 30 & Belum Tuntas \\
5 & Suryanti & 90 & Tuntas \\
6 & Yanuar Ferdianto & 70 & Tuntas \\
7 & Aji Setyawan & 50 & Belum Tuntas \\
8 & Alfareno Dwi Bagas & 60 & Belum Tuntas \\
9 & Amanda Marcela & 60 & Belum Tuntas \\
10 & Andri Setiawan & 50 & Belum Tuntas \\
11 & Asti Ramadani & 70 & Tuntas \\
12 & Dejan Purnama P. & 60 & Belum Tuntas \\
13 & Dhea Dwi Sevianti & 80 & Tuntas \\
14 & Dimas Eko Yulianto & 60 & Belum Tuntas \\
15 & Eka Nur Ramadani & 60 & Belum Tuntas \\
16 & Fiqih Firmansyah & 50 & Belum Tuntas \\
17 & Naufal Muzaki & 60 & Belum Tuntas \\
18 & Reza Fernanda & 50 & Belum Tuntas \\
19 & Yani Setyaningsih & 60 & Belum Tuntas \\
20 & Lutfi Tri Ade Har & 60 & Belum Tuntas \\
& Rata- rata & & 58 \\
& Prosentase Tuntas & & $20 \%$ \\
& Prosentase Belum Tuntas & & $80 \%$ \\
\hline
\end{tabular}

Peneliti telah mencoba mengidentifikasi masalah yang muncul pada pembelajaran IPA kelas V tentang organ pencernaan manusia di SD Negeri 2 Lumbir. Adapun identifikasi masalahnya sebagai berikut:

a. Hasil belajar siswa pada mata pelajaran IPA tentang organ pencernaan manusia yang masih dibawah ketuntasan minimal.

b. Terlalu banyak siswa yang berbicara dengan teman sebangku sehingga proses pembelajaran terlihat kurang efektif.

c. Siswa kurang memperhatikan guru ketika sedang menyampaikan materi ajar.

d. Siswa merasa kurang percaya diri dalam menjawab pertanyaan lisan yang diberikan oleh guru.

e. Terdapat siswa yang sangat sering mengucapkan kalimat yang tidak berhubungan dengan materi ajar.

f. Banyak siswa yang suka memukul meja dan kursi sehingga menimbulkan bunyi yang sangat mengganngu proses pembelajaran.

g. Siswa kurang tertarik untuk mengikuti pembelajaran IPA. 
Munculnya sebuah permasalahan dalam belajar tentulah pasti ada faktor penyebabnya. Berikut adalah analisis masalah yang telah diamati dan direfleksi oleh peneliti anatara lain yaitu:

a. Kurangnya persiapan proses pembelajaran karena guru belum membuat RPP dan belum melihat prosedur Standar Kompetensi, Kompetensi Dasar dan Indikator dalam silabus.

b. Guru belum berusaha untuk mengelola kelas secara penuh.

c. Kurangnya rasa percaya diri guru dalam proses menyampaikan materi ajar.

d. Guru belum mengembangkan cara proses pembelaharan yang lebih matang.

e. Belum adanya rasa kepercayaan dan perhatian dari guru kepada siswa untuk supaya berani menjawab dan mengemukakan pendapatnya.

f. Guru belum memberikan penekanan-penekanan materi kepada siswa yang terlalu hiperaktif.

g. Belum adanya teguran dan nasihat kepada siswa yang suka bergurau dan suka membunyikan meja dan kursi.

h. Pada awal pembelajaran, guru belum memberikan motivasi dan semangat kepada siswa untuk fokus dalam mengikuti proses pembelajaran.

i. Guru terlalu banyak menyampaikan materi yang kurang sesuai dengan silabus dan RPP.

j. Guru terlihat canggung dalam menyampaikan materi ajar.

Beberapa kajian teori dalam penelitian ini sebagaimana dipaparkan dalam uraian berikut.

\section{Hakikat Belajar}

Menurut pendapat William Brownell (1935: 1.23) dalam modul Pendidikan Matematika I S1 PGSD Universitas Terbuka menyebutkan bahwa belajar itu pada hakikatnya adalah suatu proses yang bermakna. Sedangkan menurut Ernest R. Hilgard (1948) pada modul Strategi Pembelajaran di SD S1 PGSD Universitas Terbuka (2011: 2.4) menyatakan bahwa belajar merupakan proses perubahan tingkah laku yang diperoleh melalui latihan dan perubahan itu disebabkan karena ada dukungan dari lingkungan yang menyebabkan terjadinya interaksi edukatif. Perubahan tersebut terjadi secara menyeluruh meliputi pengetahuan, sikap, dan keterampilan. Kemudian menurut Gestalt dalam (2.16) modul Strategi Pembelajaran di SD S1 PGSD Universitas Terbuka mengemukakan bahwa belajar adalah mengubah pemahaman siswa. Perubahan ini akan terjadi apabila siswa menggunakan lingkungan. Belajar adalah suatu proses yang bertujuan eksploratif, imajinatif, dan kreatif. Berdasarkan uraian di atas peneliti menyimpulkan bahwa belajar adalah suatu proses yang artinya dalam belajar akan terjadi proses melihat, membuat, $\underline{\text { mengamati, menyelesaikan masalah atau persoalan, menyimak dan latihan yang dilakukan }}$ 
secara terus-menerus dan berkesinambungan. Menurut Direktorat Ketenagaan (2006) yang dikutip pada modul Perspektif Pendidikan SD Universitas Terbuka (2009: 8.15) menjelaskan bahwa secara umum, IPA adalah pengetahuan tentang gejala alam yang dapat didefinisikan sebagai cara berfikir untuk memahami alam semesta, cara untuk melakukan investigasi, dan ilmu pengetahuan yang dihasilkan dari penyelidikan.Sebagai suatu cara berfikir, IPA merupakan aktivitas manusia yang ditandai dengan proses berfikir yang menggambarkan keingintahuan untuk memahami fenomena alam. Sebagai cara untuk melakukan investigasi, IPA merupakan gambaran pendekatan-pendekatan yang digunakan dalam menyusun pengetahuan yang dikenal dengan metode ilmiah (scientific method). Sebagai ilmu pengetahuan alam, IPA merupakan hasil kreatifitas para ilmuwan secara berabad-abad dalam bentuk penemuan yang dikumpulkan dan disusun secara sistematis.

\section{Pengertian Model Pembelajaran Think Pair Share (TPS)}

Pengertian Think Pair Share menurut Trianto (2010: 81) dikutip dari situs http://ridha90.blogspot.co.id/2013/05/hakikat-model-kooperatif-tipe-think.html pada tanggal 29 September 2016 pukul 11.06 adalah "Think Pair Share (TPS) atau berpikir berpasangan berbagi adalah merupakan jenis pembelajaran kooperatif yang dirancang untuk mempengaruhi interaksi siswa". Sedangkan menurut Suyatno (2009: 54) mengatakan bahwa "TPS adalah model pembelajaran kooperatif yang memiliki prosedur ditetapkan secara eksplinsit memberikan waktu lebih banyak kepada siswa untuk memikirkan secara mendalam tentang apa yang dijelaskan atau dialami (berfikir, menjawab, dan saling membantu satu sama lain)".

Pembelajaran think pair share merupakan pembelajaran berbasis diskusi kelas dengan kelompok siswa berpasangan. Model pembelajaran Think Pair and Share (TPS) merupakan salah satu model pembelajaran kooperatif, dimana model pembelajaran kooperatif membutuhkan partisipasi dan kerja sama dalam kelompok pembelajaran. Pembelajaran kooperatif dapat meningkatkan cara belajar siswa menuju belajar lebih baik, sikap tolong menolong dalam beberapa perilaku sosial. Menurut Sharan (dalam Isjoni, 2010:23)yang dikutip dari situs http://www.gudangteori.xyz/2016/01/pengertian-modelpembelajaran-think.html pada tanggal 29 September 2016 pukul 11.02 menyebutkan bahwa siswa yang belajar menggunakan metode pembelajaran kooperatif akan memiliki motivasi yang tinggi karena didorong dan didukung dari rekan sebaya. Jadi, siswa tidak lagi memperoleh pengetahuan itu hanya dari guru, dengan belajar kelompok seorang teman haruslah memberikan kesempatan kepada teman lainnya untuk mengemukakan 
pendapatnya dengan cara mengharagi pendapat orang saling mengoreksi kesalahan, dan saling membetulkan satu sama lainnya.

Pertama kali dikembangkan oleh Frang Lyman dan Koleganya di universitas Maryland sesuai yang dikutip Arends (1997), menyatakan bahwa think pair share merupakan suatu cara yang efektif untuk membuat variasi suasana pola diskusi kelas. Dengan asumsi bahwa semua resitasi atau diskusi membutuhkan pengaturan untuk mengendalikan kelas secara keseluruhan, dan prosedur yang digunakan dalam think pair share dapat memberi siswa lebih banyak waktu berpikir, untuk merespon dan saling membantu. Guru memperkirakan hanya melengkapi penyajian singkat atau siswa membaca tugas, atau situasi yang menjadi tanda tanya. Sekarang guru menginginkan siswa mempertimbangkan lebih banyak apa yang telah dijelaskan dan dialami. Guru memilih menggunakan think-pair-share untuk membandingkan tanya jawab kelompok keseluruhan.

\section{Langkah-Langkah Model Pembelajaran Think Pair Share (TPS)}

Langkah-langkah model kooperatif tipe Think Pair Share (TPS) menurut Suherman, Erman (2004:22) yang dikutip dari situs http://ilmu-pendidikanberbagi.blogspot.co.id/2016/03/ langkah-langkah-model-pembelajaran.html pada tanggal 29 September 2016 pukul 11.12 adalah sebagai berikut:

a) Guru menyajikan materi secara klasikal.

b) Berikan persoalan (problem) berupa pendalaman, perluasan, dan aplikasi.

c) Tugaskan siswa secara berpasangan untuk membahasnya (Think Pair).

d) Presentasikan hasil kelompok (Share).

e) Kuis individual buat skor perkembangan tiap siswa.

f) Umumkan hasil kuis.

\section{Kelebihan dan Kelemahan Penerapan Model Pembelajaran Think Pair Share} (TPS)Menurut Lie (2004: 57) yang dikutip pada situs http://edutaka.blogspot.co.id/2015/03/pembelajaran-cooperative-learning-tipe-think-pairshare.html pada tanggal 29 September 2016 pukul 11.20 berpendapat bahwa kelebihan tipe think pair share adalah sebagai berikut:

a) Memungkinkan siswa untuk merumuskan dan mengajukan pertanyaan-pertanyaan mengenai materi yang diajarkan karena secara tidak langsung memperoleh contoh pertanyaan yang diajukan oleh guru, serta memperoleh kesempatan untuk memikirkan materi yang diajarkan.

b) Siswa akan terlatih menerapkan konsep karena bertukar pendapat dan pemikiran dengan temannya untuk mendapatkan kesepakatan dalam memecahkan masalah. 
c) Siswa lebih aktif dalam pembelajaran karena menyelesaikan tugasnya dalam kelompok, dimana tiap kelompok hanya terdiri dari 2 orang.

d) Siswa memperoleh kesempatan untuk mempersentasikan hasil diskusinya dengan seluruh siswa sehingga ide yang ada menyebar.

e) Memungkinkan guru untuk lebih banyak memantau siswa dalam proses pembelajaran.

Sedangkan Kekurangan Metode Think Pair Share (TPS) Menurut Hartina (2008: 12) yang dikutip pada situs http://www.gudangteori.xyz/2016/04/kelebihan-dan-kekuranganmetode-think.html pada tanggal 27 September 2016 pukul 11.16 adalah sebagai berikut:

a) Sangat sulit diterapkan di sekolah yang rata-rata kemampuan siswanya rendah.

b) Waktu yang terbatas

c) Jumlah kelompok yang terbentuk banyak

\section{HASIL DAN PEMBAHASAN}

Subjek dalam penelitian ini adalah pada mata pelajaran IPA kelas V dengan Standar Kompetensi (SK) mengidentifikasi fungsi organ tubuh manusia dan hewan. Sedangkan yang menjadi Kompetensi Dasar (KD) yaitu mengidentifikasi fungsi organ pencernaan manusia dan hubungannya dengan makanan dan kesehatan. Kemudian yang menjadi indikator dalam penelitian ini adalah mampu menunjukkan organ-organ penyusun system pencernaan manusia beserta fungsinya. Model pembelajaran Think Pair Share adalah model pembelajaran dengan cara meminta siswa untuk berdiskusi dengan teman sebangku (think-pairs) dan kemudian presentasi kelompok (share), lalu diadakan kuis dan siswa yang mendapatkan skor tertinggi akan mendapatkan penghargaan.

Tabel 3 Hasil Belajar Siswa pada Siklus 1

\begin{tabular}{|c|l|c|c|c|c|}
\hline \multirow{2}{*}{ No } & \multicolumn{2}{|c|}{ Nama Siswa } & \multicolumn{4}{|c|}{ Siklus I } \\
\cline { 3 - 6 } & & Nilai & Naik & Belum Naik & Ket \\
\hline 1. & Didit Kurniawan & 70 & $\mathrm{~V}$ & $\mathrm{~T}$ \\
2. & Erni Ardita & 70 & $\mathrm{~V}$ & $\mathrm{~T}$ \\
3. & Kurniawan & 70 & $\mathrm{~V}$ & $\mathrm{~T}$ \\
4. & Purwanto & 50 & $\mathrm{~V}$ & $\mathrm{~V}$ & $\mathrm{~T}$ \\
5. & Suryanti & 90 & & $\mathrm{~T}$ \\
6. & Yanuar Ferdianto & 80 & $\mathrm{~V}$ & $\mathrm{~T}$ \\
7. & Aji Setyawan & 90 & $\mathrm{~V}$ & $\mathrm{~T}$ \\
\hline
\end{tabular}




\begin{tabular}{|c|c|c|c|c|c|}
\hline 8. & Alfareno Dwi Bagas & 60 & & v & BT \\
\hline 9. & Amanda Marcela & 100 & v & & $\mathrm{T}$ \\
\hline 10. & Andri Setiawan & 50 & & 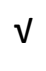 & BT \\
\hline 11. & Asti Ramadani & 70 & & $v$ & $\mathrm{~T}$ \\
\hline 12. & Dejan Purnama P. & 100 & v & & $\mathrm{T}$ \\
\hline 13. & Dhea Dwi Sevianti & 80 & v & & $\mathrm{T}$ \\
\hline 14. & Dimas Eko Yulianto & 60 & v & & BT \\
\hline 15. & Eka Nur Ramadani & 60 & & v & BT \\
\hline 16. & Fiqih Firmansyah & 80 & v & & $\mathrm{T}$ \\
\hline 17. & Naufal Muzaki & 60 & & v & BT \\
\hline 18. & Reza Fernanda & 50 & & 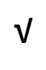 & BT \\
\hline 19. & Yani Setyaningsih & 60 & & $v$ & BT \\
\hline 20 & Lutfi Tri Ade Har & 80 & V & & $\mathrm{T}$ \\
\hline & Jumlah & 1.430 & & & \\
\hline & Rata-rata & 71,5 & & & \\
\hline & Jumlah tuntas & 12 & & & \\
\hline & Persentase tuntas & $60 \%$ & & & \\
\hline & Jumlah tidak tuntas & 8 & & & \\
\hline & Persentase tidak tuntas & $40 \%$ & & & \\
\hline
\end{tabular}

Dari tabel 3 dapat dilihat bahwa hasil belajar siswa pada siklus I, yaitu jumlah siswa yang mencapai ketuntasan adalah sebanyak 12 siswa atau $60 \%$ dari 20 siswa. Sedangkan siswa yang belum tuntas adalah sebanyak 8 siswa atau $40 \%$ dari 20 siswa. Dapat dilihat bahwa siswa kelas V SD Negeri 2 Lumbir pada perbaikan pembelajaran siklus I dalam menyelesaikan soal uraian mata pelajaran IPA tentang organ pencernaan manusia sudah cukup ada peningkatan. Siswa yang memperoleh nilai di atas KKM 7,00 sudah mencapai $60 \%$ atau 12 siswa dari 20 siswa yaitu tergambar pada warna biru, dan yang masih di bawah KKM 7,00 adalah sejumlah $40 \%$ atau 8 siswa dari 20 siswa yaitu tergambar dari warna merah. Hal ini dapat disimpulkan bahwa pembelajaran IPA tentang organ pencernaan manusia sudah cukup ada peningkatan walaupun belum bisa $100 \%$. Hasil belajar siswa pada pembeljaran siklus I dapat dilihat pada Gambar 4 sebagai berikut. 
Gambar 4. Diagram Batang Hasil Belajar pada Siklus I

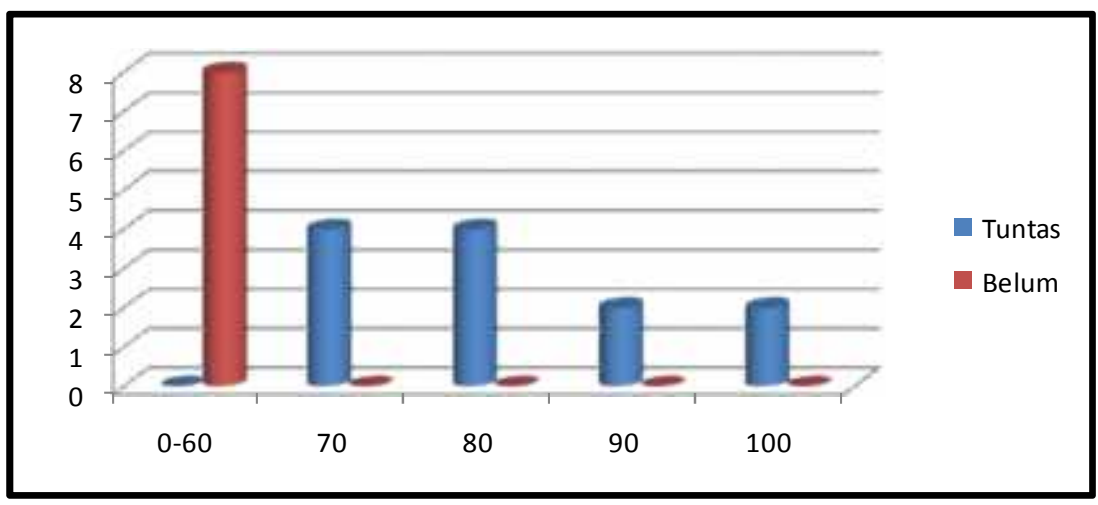

Dari Gambar 4 dapat diuraikan bahwa siswa kelas V SD Negeri 2 Lumbir dalam menyelesaikan soal uraian mata pelajaran IPA tentang organ pencernaan manusia sudah lebih banyak yang tuntas belajar walaupun belum maksimal. Siswa yang belum tuntas belajar terdiri dari 8 siswa dengan rentang nilai 0-60, kemudian 70 ada 4 siswa, 80 ada 4 siswa, 90 ada 2 siswa dan 100 hanya 2 siswa. Hal ini dapat disimpulkan bahwa pembelajaran IPA tentang organ pencernaan manusia sudah ada kenaikan dalam ketuntasan belajar.

Dalam pembelajaran awal, hasil belajar siswa kelas V SD Negeri 2 Lumbir sangatlah belum memuaskan. Setelah dilakukan analisis dan perbaikan pembelajaran pada siklus I dan II, hasil penelitian ini dapat dijabarkan sebagai berikut:

\section{Hasil Evaluasi Siswa}

Tingkat pemahaman siswa dalam memahami tentang organ pencernaan manusia pada perbaikan pembelajaran dengan menggunakan model Think Pair and Share menunjukkan peningkatan hasil evaluasi di setiap siklusnya. Berikut disajikan rekapitulasi hasil evaluasi tiap siklusnya. Berdasarkan hasil pengamatan dari pelaksanaan perbaikan pembelajaran baik pada pra siklus, siklus I maupun pada Siklus II tentang hasil evaluasi tes formatif dapat dilihat pada Tabel 6 di bawah ini.

Tabel 6 Rekapitulasi Hasil Evaluasi Siswa pada Pembelajaran

\begin{tabular}{|c|c|c|c|c|c|c|}
\hline No. & Kegiatan & Rata-rata & \multicolumn{2}{|c|}{ Siswa Tuntas Belajar } & \multicolumn{2}{c|}{ Siswa Belum Tuntas Belajar } \\
\cline { 4 - 7 } & & & Frekuensi & $\%$ & Frekuensi & $\%$ \\
\hline 1. & Studi Awal & 58 & 4 & 20 & 16 & 80 \\
2. & Siklus I & 71,5 & 12 & 60 & 8 & 40 \\
3. & Siklus II & 84,5 & 20 & 100 & 0 & 0 \\
\hline
\end{tabular}

Dari Tabel 6 tentang Rekapitulasi hasil evaluasi siswa pada pembelajaran dapat diperoleh keterangan sebagai berikut: 
a. Pada pra siklus, jumlah siswa yang tuntas ada 4 siswa dari 20 siswa dengan persentase $20 \%$ dan siswa yang belum tuntas ada 16 siswa dari 20 siswa dengan persentase $80 \%$.

b. Pada Siklus I, jumlah siswa yang tuntas ada 12 siswa dari 20 siswa dengan persentase $60 \%$ dan siswa yang belum tuntas ada 8 siswa dari 20 siswa dengan persentase $40 \%$.

c. Pada siklus II, jumlah siswa yang tuntas ada 20 siswa dari 20 siswa dengan persentase $100 \%$ dan siswa yang belum tuntas ada 0 siswa dari 20 siswa dengan persentase $0 \%$.

Dari Tabel 6 di atas tentang rekapitulasi hasil evaluasi siswa pada pembelajaran sudah ada peningkatan lebih baik, hal ini dapat dilihat pada grafik berikut:

Gambar 7 Diagram Batang Ketuntasan Hasil Belajar Siswa

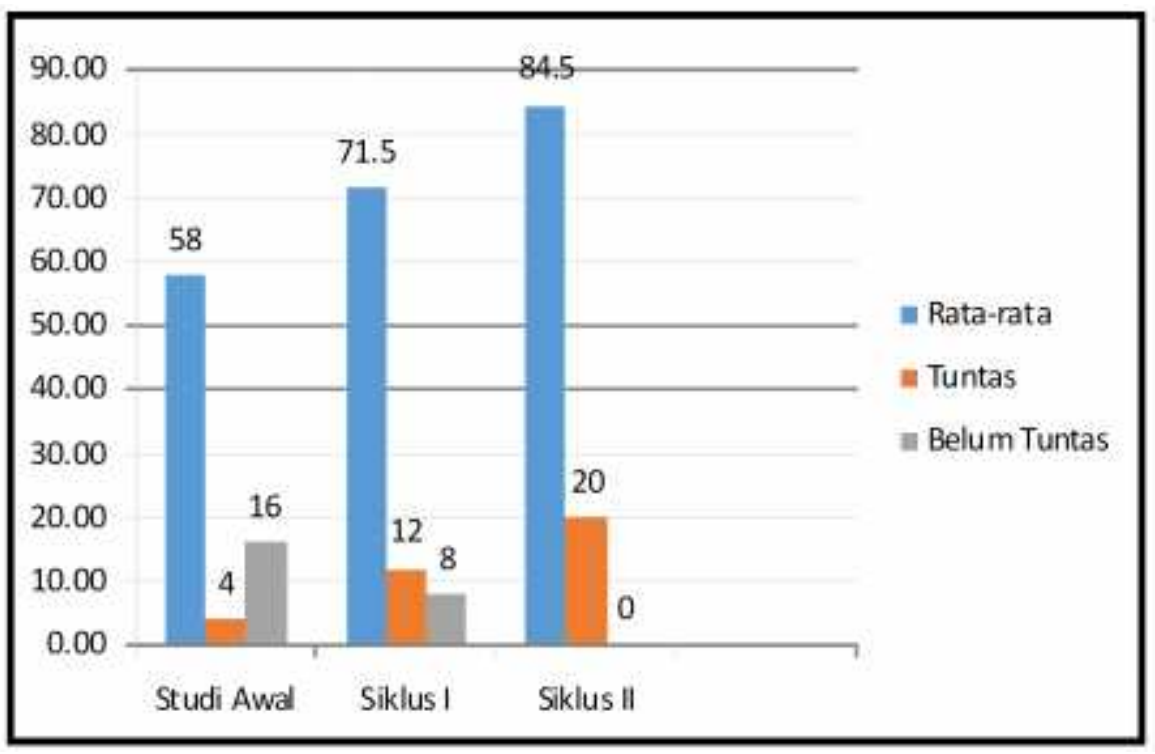

Dari Gambar 7 ketuntasan hasil belajar siswa pembelajaran dapat disimpulkan bahwa pada pra siklus, jumlah siswa yang tuntas ada 4 siswa dari 20 siswa dengan persentase $20 \%$ dan siswa yang belum tuntas ada 16 siswa dari 20 siswa dengan persentase $80 \%$ dengan rata-rata kelas 58. Sedangkan pada siklus I, jumlah siswa yang tuntas ada 12 siswa dari 20 siswa dengan persentase $60 \%$ dan siswa yang belum tuntas ada 8 siswa dari 20 siswa dengan persentase $40 \%$ dengan rata-rata kelas 71,5 . Kemudian pada siklus II, jumlah siswa yang tuntas ada 20 siswa dari 20 siswa dengan persentase $100 \%$ dan siswa yang belum tuntas ada 0 siswa dari 20 siswa dengan persentase $0 \%$ dengan rata-rata kelas 84,5 . 


\section{KESIMPULAN}

Berdasarkan hasil perbaikan pembelajaran melalui Penelitian Tindakan Kelas pada materi organ pencernaan manusia pada mata pelajaran IPA Kelas V dengan model Think Pair and Share di SD Negeri 2 Lumbir semester ganjil tahun pelajaran 2014/2015 dapat disimpulkan bahwa dengan menggunakan model Think Pair and Share dapat meningkatkan keaktifan dan hasil belajar siswa mengalami peningkatan yang cukup signifikan. Hal ini terbukti yang pada pembelajaran pra siklus hanya 4 siswa atau $20 \%$ yang tuntas KKM namun pada siklus I meningkat menjadi 12 siswa atau 60\%. Namun sebaliknya, juga terjadi penurunan ketidaktuntasan, yaitu siswa yang belum tuntas pada pembelajaran pra siklus sejumlah 16 siswa aau $80 \%$ kini setelah dilaksanakan siklus I menurun menjadi 8 siswa atau 40\% Berdasarkan ketuntasan yang ditentukan oleh penelti adalah $\geq 80 \%$, maka hasil pada siklus I ini perlu dilanjutkan pada siklus II. Pada siklus II perbaikan pembelajaran dengan menggunakan model Think Pair and Share hasil pembelajarnnya dapat dikatakan berhasil berhasil. Hal ini terbukti dari hasil belajar belajar siswa juga telah mencapai ketuntasan yang ditentukan karena pada siklus I siswa yang tuntas belajar sebanyak 12 siswa atau $60 \%$. Namun pada siklus II terjadi kenaikan yaitu menjadi 20 siswa atau 100\% sehingga pembelajaran telah berhasil. Namun demikian, pada siklus II juga terjadi penurunan presentase ketidaktuntasan belajar dari 8 siswa atau $40 \%$ yang belum tuntas pada siklus I, kini menurun menjadi 0 siswa atau $0 \%$ pada siklus II. Berdasarkan hasil perbaikan pembelajaran pada siklus II, maka peneliti menganggap bahwa perbaikan pembelajaran tentang organ pencernaan manusia pada mata pelajaran IPA kelas IV di SD Negeri 2 Lumbir tahun pelajaran 2014/2015 sudah berhasil dan dinyatakan berakhir.

\section{SARAN}

Perlu dilakukan penelitian tindakan kelas dnegan menggunakan metode pembelajaran yang lain

\section{DAFTAR PUSTAKA}

Brownell,William. (2012). Modul 1. Pembelajaran Matematika di SD. Pendidikan Matematika I. Tangerang Selatan. Penerbit: Universitas Terbuka.

Djamarah. (2016), Peningkatan Hasil Belajar Matematika Operasi Hitung Campuran Bilangan Bulat Melalui Pengggunaan Alat Peraga "KOPOTIF” Bagi Siswa Kelas V 
SD Negeri Somagede. TUT WURI Jurnal Penelitian dan Pengembangan Pendidikan, 4 (1), hal.46.

Direktorat Ketenagaan. (2009). Modul 8. Kurikulum Sekolah Dasar: Perspektif Pendidikan SD. Jakarta: Penerbit Universitas Terbuka.

Gestalt. (2011). Modul 2. Pembelajaran Di Sekolah Dasar: Strategi Pembelajaran di SD. Jakarta: Pusat Penerbit Universitas Terbuka.

Heinic, dkk. (2012). Modul 5. Media Dan Alat Peraga Dalam Pembelajaran IPA: Pembelajaran IPA di SD. Tangerang Selatan: Penerbit Universitas Terbuka.

Kurikulum 2004. (2012). Modul 2. Pendekatan Dalam Pembelajaran IPA SD: Pembelajaran IPA di SD. Tangerang Selatan: Penerbit Universitas Terbuka.

R. Hilgard, Ernest. (2011). Modul 2. Pembelajaran Di Sekolah Dasar: Strategi Pembelajaran di SD. Jakarta: Pusat Penerbit Universitas Terbuka.

Romizoswki. (2011). Modul 2. Pembelajaran Di Sekolah Dasar: Strategi Pembelajaran di $S D$. Jakarta: Pusat Penerbit Universitas Terbuka.

Sudjana. (2009). Modul 1. Konsep Dasar PKM. Pemantapan Kemampuan Mengajar (PKM)-PGSD. Jakarta: Pusat Penerbit Universitas Terbuka.

TIM-FKIP. (2012). Modul 1. Konsep Dasar PKM: Pemantapan Kemampuan Mengajar $(P K M)-P G S D$. Tangerang Selatan: Pusat Penerbit Universitas Terbuka.

Undang-undang Nomor 20 Tahun 2003 Tentang Sistem Pendidikan Nasional

Erman, Suherman. (2004). Diunduh tanggal 29 September 2016 pukul 11.12 dari http://ilmu-pendidikan-berbagi.blogspot.co.id/2016/03/langkah-langkah-modelpembelajaran.htm

Hartina. (2008). Diunduh tanggal 27 September 2016 pukul 11.16 dari http://www.gudangteori.xyz/2016/04/kelebihan-dan-kekurangan-metode-think.html 